\title{
The identity of Hemeroblemma lienaris Hübner and a review of the neotropical moths of the pannosa-complex of Epidromia Guenée (Noctuidae, Catocalinae)
}

\author{
Vitor O. Becker ${ }^{1}$
}

\begin{abstract}
Epidromia lienaris (Hübner, 1823) comb. $\mathbf{n}$. is the oldest name for the species later described as E. pannosa Guenée, 1852, syn. n., E. zetophora Guenée, 1852 syn. n., Thermesia glaucescens Walker, 1858 syn. n., T. suffusa Walker, 1858 syn. n., T. tinctifera Walker, 1858 , syn. n., T. lenis Walker, 1858 syn. n., T. valida (Walker, 1865) syn. n., Ophisma antica Walker, 1865 syn. n., E. xanthogramma Wallengren, 1860 syn. n. and E. rotundata Herrich-Schäffer, 1869 syn. n.; E. poaphiloides (Guenée, 1852), is regarded the senior name for Ophiusa profana Walker, 1858 syn. n. and Remigia saturatior Walker, 1858 syn. n. Manbuta pyraliformis (Walker, 1858), comb. n. and $M$. nigrisparsa (Dognin, 1914), comb. n., are removed from Epidromia Guenée, 1852 and Iluza Walker, 1865 respectively.

KEY WORDS. Noctuidae, Epidromia, Hemeroblemma, Manbuta, Neotropical, synonymy
\end{abstract}

Hemeroblemma lienaris Hübner (1823: 17) has been regarded as an unrecognized species since its description. The figures of the type, rather crude, in HÜBNER (1823: pl. [49], figs 277, 278), reproduced here (Fig. 1), resemble some of the species currently in Azeta Guenée, 1852 and in Epidromia Guenée, 1852 especially $A$. signans (Walker, 1858), and certain forms of the $E$. pannosa Guenée, 1852 complex. In A. signans the ground colour of both wings is uniform either basad and distad of the postmedial line, and show a row of dots half way between this line and the external margin, whilst in Epidromia the ground colour is much paler outside the postmedial line, and the row of dots is absent (Fig. 2). The same differences are shown in the underside of both wings. In A. signans there are two parallel lines followed by the row of dots, whilst in Epidromia there is only one line, darker than ground colour. These characters indicate that $H$. lienaris represents one of the several forms of an extremely polymorphous species of Epidromia, as discussed below, and not any of the Azeta species.

For a long time the author had suspected that the species formerly known as E. pannosa Guenée, E. zetophora Guenée, and several others described by WALKER $(1858,1865)$, listed below, were not more than different forms of one polymorphous species. Aware of this, special attention was given to this group by the author during his collecting trips, resulting in the accumulation of a series of over 150 specimens representing all the different forms. A study of this material, currently in the author's collection (VOB), as well as the type material and colour pictures of types deposited in the collections of the Natural History Museum, London (BMNH), University

1) Departamento de Zoologia, Universidade de Brasilia. Caixa Postal 04525, 70919-970 Brasília, Distrito Federal, Brasil. Research Associate. 
Museum, Oxford (UMO), the National Museum of Natural History, Washington (USNM), the Instituto de Ecología y Sistemática, Havana (IES) and the Naturhistoriska Riksmuseet, Stockholm (NR) confirmed this suspicion, as discussed below.

POOLE (1989: 362) transferred the Antillean Thermesia pyraliformis Walker, 1858 , with its seven synonyms, to Epidromia. An examination of its genitalia, as well as the strongly pectinated antennae, revealed that this species is congenerous with others currently in Manbuta Walker, 1865 comb. n.. Iluza nigrisparsa Dognin, a South American species very similar to $M$. pyraliformis, is also a member of Manbuta comb. $\mathbf{n}$.

\section{Epidromia lienaris (Hübner, 1823), comb. $\mathbf{n}$.}

Figs 1,2

Hemeroblemma lienaris Hübner, 1823: 17, pl. [49], figs 277, 278. Neotype male, BRAZIL: Distrito Federal, Planaltina, 1100 m, 15.II.1994 (Becker) (VOB, 96991), here designated.

Epidromia pannosa Guenée, 1852: 326. Lectotype male, BRAZIL [no further data] [BMNH], here designated [examined]. Syn. $\mathbf{n}$.

Epidromia zetophora Guenée, 1852: 326. Holotype male, BRAzIL [no further data] [not traced, presumably lost]. Syn. $\mathbf{n}$.

Thermesia suffusa Walker, 1858: 1561. Holotype female, [DominiCAN REPUBLIC]: "St. Domingo" (BMNH) [examined]. Syn. $\mathbf{n}$.

Thermesia tinctifera Walker, 1858: 1570. Holotype female, Hondur^s [no further data] (BMNH) [examined]. Syn. $\mathbf{n}$.

Thermesia glaucescens Walker, 1858: 1571. Holotype female: [BRAZIL: Pará, Belém] "Pará" (BMNH) [examined]. Syn. $\mathbf{n}$.

Thermesia lenis Walker, 1858: 1572. Types(s): [BRAZIL: Pará, Belém] "Pará" (UMO) [not examined]. Syn. $n$.

Epidromia xanthogramma Wallengren, 1860: 174. Holotype female, [PERU: Lima], Callao [NR] [colour picture examined]. Syn. $\mathbf{n}$.

Thermesia valida Walker, 1865: 953. Holotype male, [Dominican Republic]: "St. Domingo" (BMNH) [examined]. Syn. $\mathbf{n}$.

Ophisma? antica Walker, 1865: 954. Holotype male, VeNEzuELA [no further data] (BMNH) [examined]. Syn. $\mathrm{n}$.

Epidromia rotundata Herrich-Schäffer, 1869: 159. Lectoype male, CUBA: "292" [no further data] (Gundlach) (IES), here designated [examined]. Syn. n.

This is a very common species in the neotropics, ranging from Southern United States, throughout the Antilles, South to Brazil and Argentina, and extremely polymorphous, the reasons why it has been described so many times. In one single expedition [BRAZIL: Goiás, Alto Paraíso, 1400m, 1-6.XI.1996 (VOB 98476)] a series of 53 specimens was collected from one sheet, attracted to a $250 \mathrm{~W}$ MV bulb. Specimens from these series matched the types of nearly all the forms listed in the synonymy above, as well as the figures of the types of both E. lienaris (HÜBNER 1823: pl. [49], figs 277, 278] and E. zetophora (GUENÉE 1852: pl. 23, fig. 5). The genitalia of all these forms, illustrated by SoLís (1986: 16), as E. pannosa, confirmed the suspicion that they belong to a single species.

The difference in hind wing shape between the figure of $E$. lienaris [female] (Fig. 1) and that of the male NEOTYPE illustrated here (Fig. 2), is sexual. Males have middle of margin of hind wings expanded, forming an angle, whilst the females have the margin almost evenly round. 

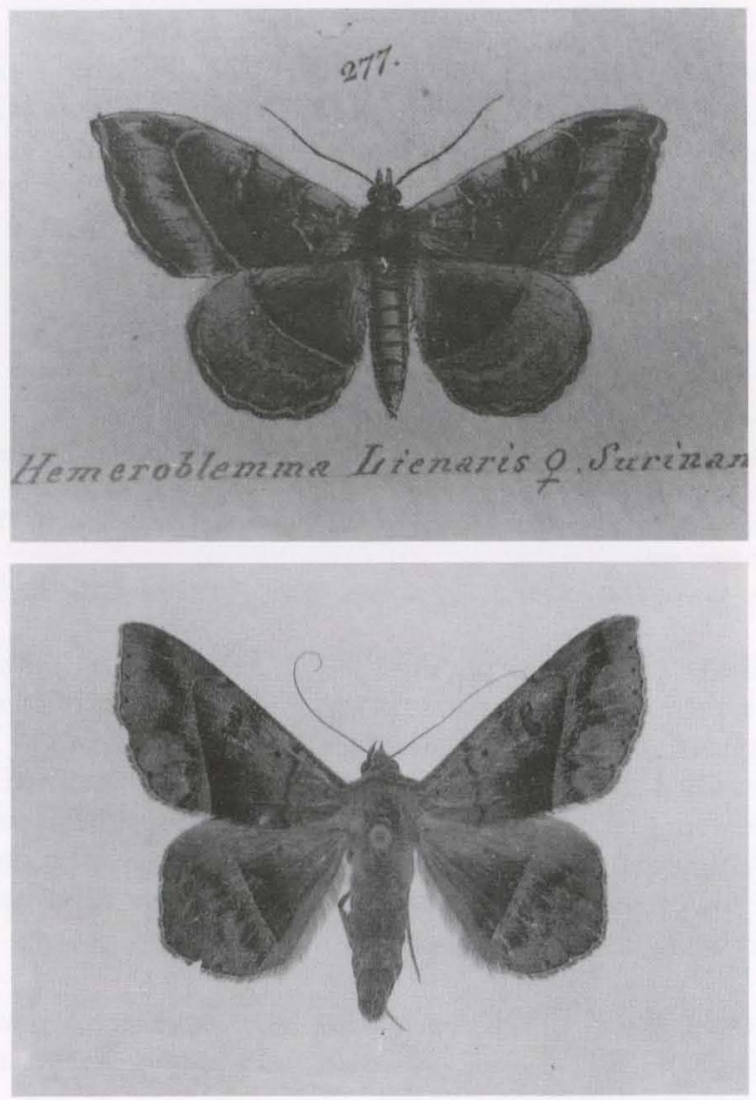

Figs 1-2. Adults of Epidromia lienaris. (1) Figure of female type in Hübner; (2) male neotype.

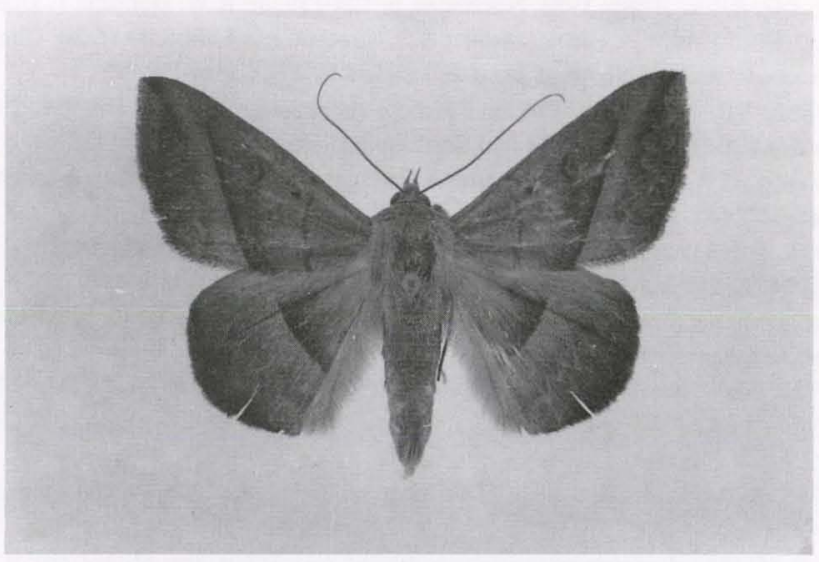

Fig. 3. Epidromia poaphiloides, male. 
SCHAUS (1896: 638) had already synomized $T$. lenis with E. pannosa and FRANCLEMONT \& TODD (1983) synonymized E. pannosa, Ophiusa profana and Ophiusa delinquens Walker under E. poaphiloides. Solís (1986: 13) and POOLE (1989: 362) removed $E$. pannosa, $O$. profana and $E$. lenis from synonymy and transferred $O$. delinquens to Mocis Hübner, [1823] as a junior synonym of M. latipes (Guenée, 1852). [see more details under E. poaphiloides below].

\section{Epidromia poaphiloides (Guenée, 1852)}

Fig. 3

Bendis poaphiloides Guenée, 1852: 215. Syntypes females, [FRENCH GuIANA]: Cayenne (Feisthamel) [not traced, presumably lost].

Ophiusa profana Walker, 1858: 1423. Holotype male, [BrazIL: Pará, Belém]: "Pará" (BMNH) [examined]. Syn. rev.

Remigia saturatior Walker, 1858: 1503. Holotype male, BRAZIL. [no further data] (BMNH) [examined]. Syn. $n$.

In VOB there are five males (VOB 17972, 34867, 98476, 114882), all from Brazil, that match the types of the two synonyms. The genitalia of these specimens are identical to each other but different from those of E. lienaris.

The identity of $E$. poaphiloides is questionable as no specimen belonging to the type series were found neither in the BMNH (M. Honey, pers. comm.), nor in the Museum Nationale d'Histoire Naturelle, Paris (C. Lemaire, pers. comm.), where the type material of the species described by Guenée are deposited. However, Guenée's description matches this species.

ACKNOWLEDGEMENTS. This work could not be finished without the help provided by Mr. M. Honey (BMNH), Dr. C. Lemaire (Paris), and Dr. B. Gustafsson (NR), and Mr. K. Preston-Maphan (PREMAPHOTOS, England).

\section{REFERENCES}

Franclemont, J.G. \& E.L. TodD. 1983. Noctuidae, p. 120-159. In: R.W. HodGes; T. Dominicki; D.R. Davis; D.C. Ferguson; J.G. Franclemont; E.G. Monroe \& J.A. Powell. (Eds). Check list of the Lepidoptera of America North of Mexico. London, E.W. Classey.

GuenÉE, A. 1852. VII. Noctuélites. III. In: J.B.A.D. DE BoIsDuval \& A. GuenÉe (Eds). Histoire

Naturelle des Insectes. Species général des Lépidoptères. Paris, Roret, $441 \mathrm{p}$.

Herrich-SChÄfFer, G.A.W. 1869. Die Schmetterlinge der Insel Cuba. CorrespBI. zool.-min. Ver.

Regesnburg 23: 153-160.

HÜBNER, J. 1823. Zuträge zur Sammlung exotischer Schmetterlinge. Augsburg, 32p.

Poole, R.W. 1989. Noctuidae. I. Lepid. cat., n. ser., 118: 1-500.

Schaus, W. 1896. On the Walker's American types of Lepidoptera in the Oxford University Museum.

Proc. zool. Soc. Lond. 1896: 634-650.

Solis, M.A. 1986. A new species of Epidromia (Noctuidae) from Florida. Jour. Lepidop. Soc. 40: 8-19. WALKER, F. 1858. List of the specimens of lepidopterous insects in the collection of the British

Museum 15, p. 1521-1888.

- 1865. List of the specimens of lepidopterous insects in the collection of the British Museum 33, p. 707-1120.

WaLlengren, S.M. 1860. Lepidopterologische Mittheilungen. Wien. ent. Monatschr. 4: 161-176.

Recebido em 21.II.2001; aceito em 27. VIII. 2001. 